Future Directions in Feminist Phenomenology

The University of Western Ontario, London, Ontario

May 23-25, 2013

David Chu International Centre, WSS 2130

Dr. Gail Weiss, The George Washington University

Friday May 23, 10:20 a.m.

\title{
Beauvoir, Irigaray, and the Ambiguities of Desire
}

\begin{abstract}
This essay argues that by insisting upon the existential and ethical significance of what Linda Martín Alcoff calls our "visible identities" (most notably our gender and race), and by drawing our attention to the ways in which sexism and racism deny the ambiguity of far too many individuals' existences, Simone de Beauvoir anticipates and sets the stage for Luce Irigaray's materialist analyses of how systemic social and political oppression generates false hegemonies of desire and pleasure based on denial and lack rather than multiplicity and jouissance. Despite significant differences in their depictions of the existential possibilities opened up by desire, Beauvoir and Irigaray are equally committed to undermining traditional, solipsistic conceptions of desire and affirming a relational ontology, animated by desire, as the proper ground for ethics and politics. Insofar as my desires and the desires of others are expressions of, and responsive to, our changing physical, social, political, economic, and historical situations, so too, Beauvoir and Irigaray are suggesting, must our ethics and politics affirm these lived ambiguities that define human existence.
\end{abstract}

